\title{
Assessment of Health Status of the Elderly and Pre-elderly at a Malaysia Elderly Care Centre
}

\author{
Nurul Aini Bani ${ }^{1 *}$, Mohamad Zaki Hassan ${ }^{1}$, Hazilah Mad Kaidi ${ }^{1}$, Nor Fazilah \\ Mohd Hashim ${ }^{1}$, Rudzidatul Akmam Dziyauddin ${ }^{1}$, Rafizah Musa ${ }^{1}$, Mohamed \\ Azlan Suhot ${ }^{1}$, Sahnius Usman ${ }^{2}$, Firdaus Muhammad-Sukki ${ }^{3}$, Siti Hawa Abu- \\ Bakar $^{4}$, Abdullahi Abubakar Mas'ud ${ }^{5}$
}

${ }^{1}$ Razak Faculty of Technology and Informatics,

Universiti Teknologi Malaysia, Jalan Sultan Yahya Petra, Kuala Lumpur, 54100, MALAYSIA

${ }^{2}$ UTM School of Professional and Continuing Education,

Universiti Teknologi Malaysia, Jalan Sultan Yahya Petra, Kuala Lumpur, 54100, MALAYSIA

${ }^{3}$ School of Engineering,

Robert Gordon University, Aberdeen AB10 7GJ, UNITED KINGDOM

${ }^{4}$ British Malaysian Institute, Universiti Kuala Lumpur,

Gombak 53100, Selangor, MALAYSIA,

${ }^{5}$ Department of Electrical and Electronic Engineering Technology,

Jubail Industrial College, Jubail 31961, SAUDI ARABIA

*Corresponding Author

DOI: https://doi.org/10.30880/ijie.2018.10.07.002

Received 29 October 2018; Accepted 14 November 2018; Available online 30 November 2018

\begin{abstract}
They were once called the baby boomers, born between 1946 to 1964, but now aged above 50 years old, they contribute to the increasing number of elderly population in Malaysia. Age classification for elderly people varies between countries but commonly pre-elderly people is defined as those aged between 50 to 64 years old while those aged more than 64 years old fall in elderly category. In Malaysia, it is projected that the elderly population will make up for $10 \%$ of the total population or 3.4 million by year 2020. Without effective and comprehensive healthcare system, the healthy lifestyle of this elderly population can be affected thus prohibiting them to return to their premorbid function. In this study, the health status of pre-elderly and elderly community residing at an Elderly Care Center in Selangor, Malaysia is assessed. In overall, 12 male occupants (4 elderly and 8 pre-elderly people) aged 50 years and above were interviewed to obtain data on their sociodemographic characteristics, medical history, hand functionality and hand strength measurements. The overall sample mean (standard deviation) age are 63 (8) years. The mean (standard deviation) for BMI is $20.26(2.73) \mathrm{kg} / \mathrm{m}^{2}$ that falls in the normal category despite the visible nutritional deficiencies sign and symptoms on their physical body and facial. The mean (standard deviation) of handgrip measurements is $12.47(6.69) \mathrm{kg}$, which is quite low but reasonable due to ageing factor.
\end{abstract}

Keywords: Malnutrition, Handgrip strength measurement, Sociodemographic, ANOVA, elderly care centre 


\section{Introduction}

Based on United Nations (UN) projections, Malaysia is expected to become an ageing country in 2030 when Malaysian population aged 60 years and above reaches 15 per cent of the nation's total population (United Nation, 2013). In Malaysia, elderly citizens are defined by those aged 60 years and over (World Assembly on Aging, 1982, World Health Organization, 1989 \& Ministry of Health, 1999). The Department of Statistics Malaysia (The Department of Statistics Malaysia, 2017) estimated an increase of $1.3 \%$ in total population of Malaysia in 2017, amounted to 32 million populations. Subsequently, the elderly population of aged 65 years and above is estimated to be 2 million elderly people, an increase of $0.2 \%$ from the estimated population in 2016. As a result, Malaysia is projected to experience ageing population by 2020 as the percentage of elderly population rise up and exceeds $7 \%$ of the total population (The Department of Statistics Malaysia, 2016). The longevity of the elderly population is expected to increase to 0.2 years for both male and female in 2017. This indicates that the elderly people are expected to live longer every year (The Department of Statistics Malaysia, 2016). Thus, those in their pre-elderly age will in a few years also contribute to the statistics of the elderly population.

Collectively, the high number of elderly and pre-elderly population every year and the increased life expectancy can have major impact on the country's health care system if not geared with advanced technologies and good health management. There are a number of chronic diseases associated with ageing population such as Alzheimer, arthritis, lung disease, stroke, osteoporosis and malnutrition (Lunenfeld \& Stratton, 2013). Malnutrition in elderly population can be caused by medical, social and psychological factors (Hickson, 2006). Typical risk factors for malnutrition are poor appetite, physical disability that affected the ability to feed or reach food, endocrine disorders such as diabetes thus limited the choice of food, oral problems that affected the ability to swallow the food and other disease states or nursing support quality that may contribute to under-nutrition as well as over-nutrition (Hickson, 2006).

Several studies (Harding, 2016 \& Özbilgin et al., 2016) have been conducted to investigate the relationship between malnutrition and muscle condition. Muscle wasting and muscle loss have been associated with elderly population in many studies (Harding, 2016). The conditions of our muscle can be an indicator of morbidity and mortality in patients and it can be predicted using nutritional status assessment (Özbilgin et al., 2016). There are a number of nutrition assessment tools are available to recognize patients who are under-nutrition and over-nutrition such as Malnutrition Universal Screening Tool (MUST) (Chao et al., 2015 \& Keetarut et al., 2017), Scored Patient-Generated Subjective Global Assessment (PG-SGA) (Kim et al., 2013 \& Shahvazi et al., 2017), Mini Nutritional Assessment (MNSA) (Kim et al., 2013), hand grip strength (HGS) (Vaz et al., 1996, Sharma et al., 2017, Jensen et al., 2017 \& Bani et al., 2017) and many more. Several studies on HGS as a general indicator of multiple chronic diseases such as chronic kidney disease (ElKatab et al., 2015 \& Chang et al., 2011), arthritis (Nunes et al., 2012 \& Dedeoglu et al., 2013), coronary artery disease (Sokran et al., 2015) and De Quervain Tenosynovitis (Ahmad et al., 2013) have been conducted and the results are conclusive; there is a close correlation in predicting chronic disease of a patient using HGS. In addition, HGS can also predict a decline in function of elderly population (Taha \& Sulaiman, 2011) as well as an indicator for nutritional status in individuals with chronic malnutrition (Luna et al., 2005, Schlussel et al., 2008 \& Kamarul et al., 2006). Moreover, physical activities i.e. training and exercise, have become an important element in promoting active and healthy aging, increase the rate of longevity, improve physical functionality and quality of life especially for those in ageing population (Bidaurrazaga-Letona et al., 2017).

This is a pilot study conducted in an elderly care centre in Selangor, Malaysia. This elderly care centre take care of elderly people who are childless, have no surviving spouse or unfortunately disregarded by their family when they were discharged from government hospital but requires further medical follow-up care in terms of hospital appointments and physiotherapy treatments. There are also those who came to the centre without being persuaded by anyone, not wanting to become a burden to their family and care-givers. The care centre is located in a remote rubber estate area and most of the days, the surrounding is quiet and gloomy. This mundane atmosphere can cause high depression and stress among the population. Moreover, the centre is not designed to stimulate physical movements and encourage thinking thus contribute to the mental, emotional and health problems of the occupants.

In this study, a structured questionnaire on sociodemographic characteristics, medical history and hand functionality was conducted on elderly and pre-elderly community. A handgrip strength measurement was also conducted to investigate the relationship between handgrip strength and chronic diseases. The hand functionality and disabilities of the occupants were assessed using a validated hand assessment questionnaire. This study is part of a rehabilitation program conducted at the care centre towards imposing positive impact on the quality of life of the Elderly Care Centre occupants. 


\section{Methodology}

This section describes the methodology used for this study.

\subsection{Data Collection}

All subjects aged from 50 years old and above were invited to participate in this study. The exclusion criteria for participation were those without limb and limb deformation. Subjects with upper limb injury, dysfunction of the elbow joint, had undergone surgery related to hand within the last three months were invited to participate and their physical condition were acknowledged.

Before the start of the study, subjects were interviewer-administered to provide information on background history, demographic data, health status, hand functionality and lifestyle routine. The interview is conducted in Bahasa Malaysia throughout the interview session. To calculate the body mass index (BMI), height and weight must be measured. Since most of the elderly were unable to stand properly and tend to hunch forward, the height is estimated using the ulna length. Based on (BAPEN, 1992), the ulna length must be measured between the point of the elbow (olecranon process) and the midpoint of the prominent bone of the wrist (styloid process) at their left side if possible as shown in Fig. 1 below. The height of the subject is by comparing the ulna length value and the subject's age [30]. The BMI can be determined by diving the body weight measured in kilogram $(\mathrm{kg})$ by the square of the estimated body height in meters $(\mathrm{m})$.

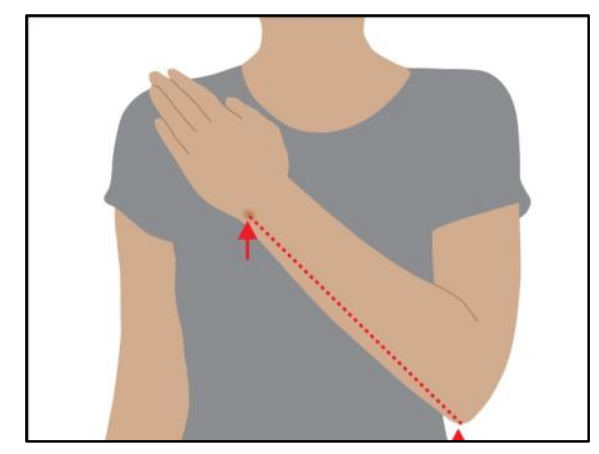

Fig. 1 - Measurement of ulna length. Picture taken from (BAPEN, 1992).

For handgrip strength, a Digital Pinch / Grip Analyzer from MIE Ltd will be used throughout the data collection as shown in Fig. 2 (MIE Medical Research Ltd, 2015). This analyzer is a precision instrument specifically designed to ensure maximum accuracy and resolution. This instrument is chosen because of its lightweight handle construction thus allowing patients with very poor strength especially the elderly to perform the strength test efficiently. The handle is also insensitive of grip placement as it incorporates a unique sensor to generate correct readings at all times. The handle width is set to a common scale value so that the tests are comparable. The digital analyzer provides force values in Newtons force, kilograms or pounds with the values shown at the digital display of the multi-analyzer. The force values are then captured by a CAS Software incorporated in the analyzer and relevant analysis can be conducted by the software (MIE Medical Research Ltd, 2015).

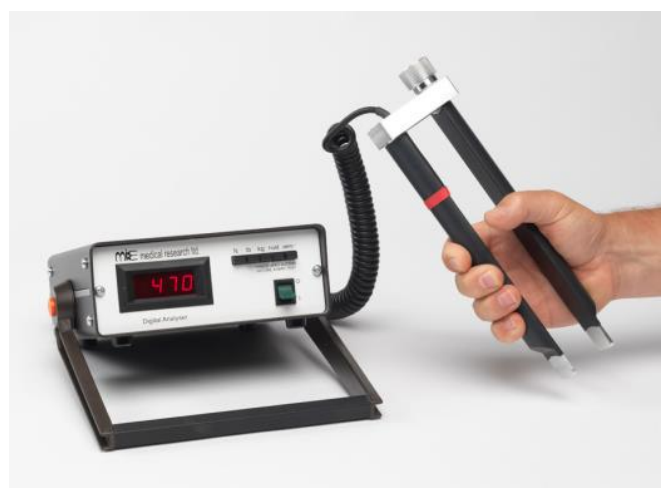

Fig. 2 - Hand grip and pitch digital analyzer from MIE Ltd UK. Picture taken from [31].

For handgrip strength measurement, due to the poor health of the elderly, the measurement was taken with participants seated on the chair following the standard position by American Society of Hand Therapy (ASHT) (1981). as shown in Fig. 3. Subjects are instructed to be in seating position with the elbow flexed at 90 degrees, wrist and forearm in a neutral position with the forearm lying on an armrest. This is to ensure that their hand is free to squeeze the handles 
but neither the hand nor the handle should touch the body or any other object during the test. Their feet were ensured to be flat on the floor and they did not leave the ground during the test. Prior to the commencement of data collection, subject will be allowed to do a practice trial to familiarize the handles. Before testing, the examiner will demonstrate how to hold the handles properly. Subjects will be asked to hold the grip analyzer handles $2 \mathrm{~cm}$ down from the red indicator line without support. Three handgrip measurements are taken on seated position on dominant or functional hand only with 5 seconds of maximal hand gripping. Subjects are given a 10-second rest between the measurements to minimize fatigue. Subjects received no feedback but were given consistent verbal encouragement for each test to ensure maximal effort. All tests are conducted by the same examiner to control inter-tester variability. All data are saved under the condensed format and subsequently converted to required format of the pre-processing techniques.

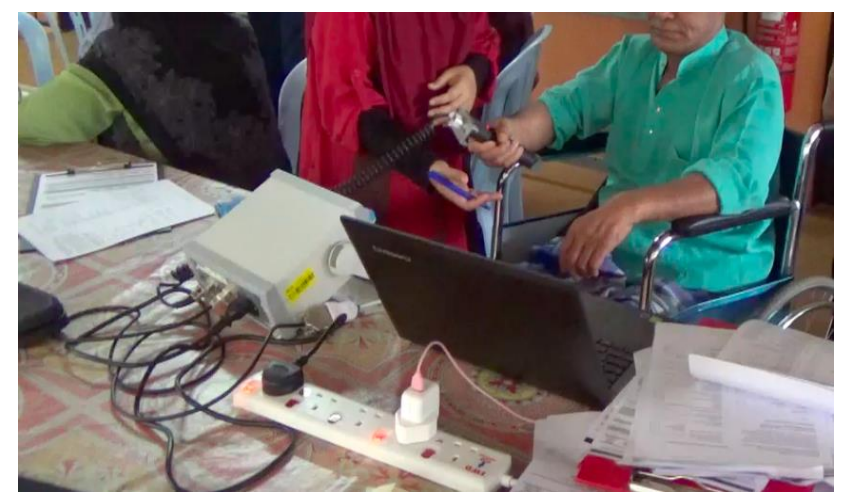

Fig. 3 - Seating position during hand grip measurement

For hand functionality and disability assessment, subjects were interviewer-administered using a shortened version of The Disabilities of the Arm, Shoulder and Hand Score (QuickDash) questionnaire. This questionnaire requires information regarding subjects' symptoms as well their ability to perform certain activities such as opening a new jar, carrying a shopping bag, performing recreational and daily activities, difficulty to sleep and many more. There are a total of 11 questions with each question has 5 response options and individually scaled. To calculate the QuickDASH score, at least 10 of the 11 questions must be answered where higher scores indicate severe level of disability and lower scores indicate mild disability with zero score means no disability.

\subsection{Data Analysis}

All statistical analysis are performed using SPSS software (SPSS 16). Descriptive statistics include of frequencies, percentages, means and standard deviations (SD) are used to analyze the characteristics of the participants. An independent t-test is used to determine the relationship of handgrip between elderly subjects (aged 66 years and above) and pre-elderly subjects (aged between 50-64 years). A p $\leq 0.05$ probability level is used to indicate significance in all of the statistical analyses.

\section{Results and Discussion}

The results of this study are discussed based on the questionnaire categories.

\subsection{Demographic Characteristics}

There was a total of 12 male participants with the age range between 50 to 79 years old. 4 subjects fall in pre-elderly category $(\mathrm{N}=4)$ and the other 8 subjects are in elderly category $(\mathrm{N}=8)$. Table 1 shows the clinical characteristics of subjects for pre-elderly and elderly group. These two groups have similar systolic blood pressure, diastolic blood pressure and random blood glucose (RBS). Fig. 4 shows the percentage of gender and race of the occupants while Fig. 5 tabulates the sociodemographic characteristics and occupation history of the occupants from an Elderly Care Centre. Majority $(83.33 \%)$ of the care centre occupants are from Malays ethnic and the rest (16.67\%) are from Indian ethnic. A total of 6 $(50.00 \%)$ occupants have been married, $3(25.00 \%)$ are still single while $3(25.00 \%)$ have been divorced or widowed before living at the care centre. Mostly all of the occupants $(\mathrm{n}(\%)=11(91.67 \%)$ people) had attended school during their school year. The lowest education level is reported to be in elementary Year 2 while the highest education level is achieved by one of the occupants $(9.10 \%)$ who attended tertiary education level at local university. However, he did not manage to complete his tertiary education. All occupants (100\%) have worked before to support their daily lives whether in fieldwork or office work such as rubber tappers, village work and security guard. About 7 (58.33\%) occupants used to live in urban areas in different states while the remaining $5(41.47 \%)$ occupants lived in suburban. 
Table 1 - Characteristics of the studied sample

\begin{tabular}{|c|c|c|c|c|c|c|}
\hline \multirow[t]{2}{*}{ Characteristics } & \multirow[t]{2}{*}{ Units } & \multicolumn{2}{|c|}{ Pre-elderly } & \multicolumn{2}{|c|}{ Elderly } & \multirow[t]{2}{*}{ p-value } \\
\hline & & Mean & SD & Mean & SD & \\
\hline Age & years & 55.50 & 3.416 & 68.25 & 5.800 & 0.003 \\
\hline Systolic BP & $\mathrm{mmHg}$ & 146.00 & 22.136 & 137.38 & 31.22 & 0.635 \\
\hline Diastolic BP & $\mathrm{mmHg}$ & 84.75 & 18.626 & 82.50 & 9.842 & 0.785 \\
\hline RBS & $\mathrm{mmol} / \mathrm{l}$ & 11.75 & 6.572 & 7.81 & 2.735 & 0.163 \\
\hline
\end{tabular}

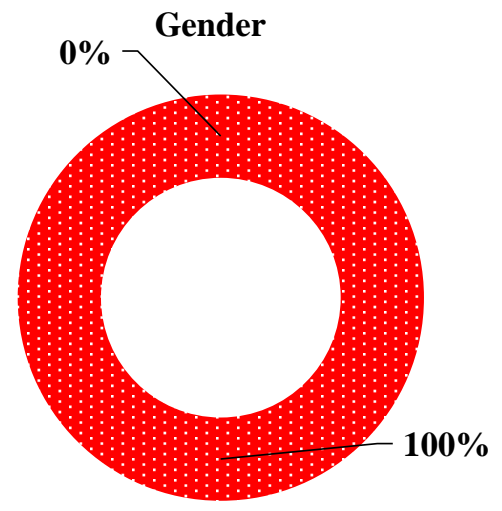

Male \& Female

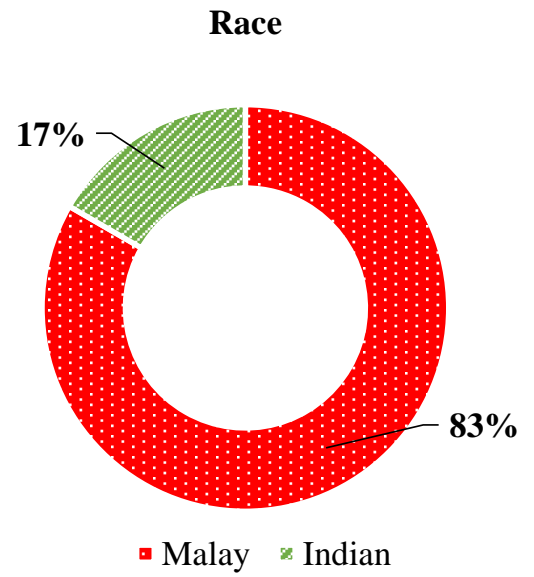

- Malay z Indian

Fig. 4 - Percentage of gender and race of the study sample

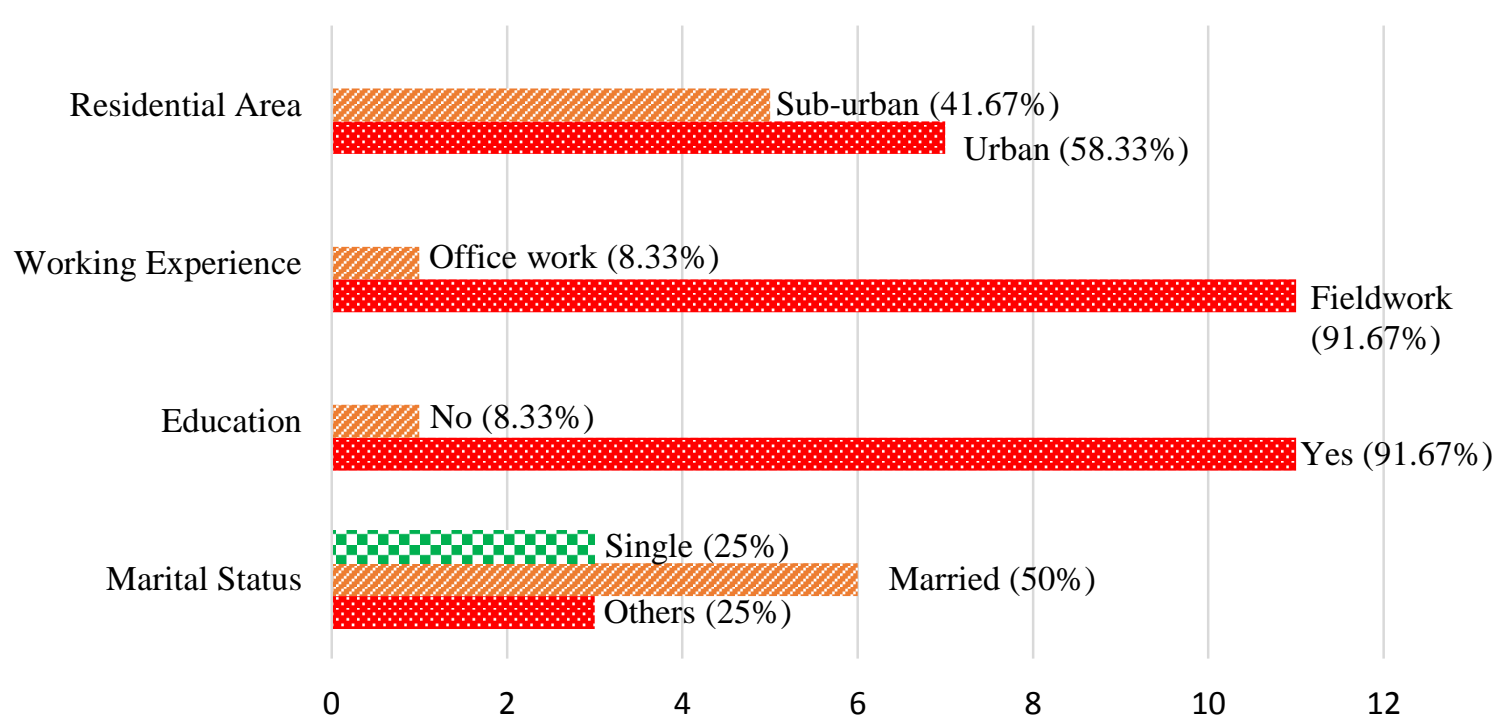

Fig. 5 - Sociodemographic characteristics and occupation history of the study sample

\subsection{Medical History and Health Status}

Table 2 shows the distribution of weight and smoking prevalence of the study sample. The mean (SD) weight of the study sample is $65.24(7.49) \mathrm{kg}$. As mentioned in the Methodology section, the estimated height was calculated using ulna measurement and age (in years) of the participants since most of the elderly were unable to stand properly and tend to hunch forward. The mean (SD) height of the study sample is $1.80(0.05) \mathrm{m}$. The mean (SD) BMI falls in the normal and healthy weight category (BMI > $\left.18.5 \mathrm{~kg} / \mathrm{m}^{2}\right)$ at $20.26(2.73)$ with three pre-elderly subjects in underweight $(\mathrm{BMI}<$ $18.5 \mathrm{~kg} / \mathrm{m}^{2}$ ) category. Almost all subjects have no problem with food intake except some residents who need nutrition intervention because of diabetes problem. When asked regarding their weight management as compared to the previous months, only two subjects acknowledged the reduction in their weight, 6 subjects confirmed their unchanged weight while 4 subjects admitted the increased in their weight.

Hypertension and diabetes are common diseases within the care centre community as more than $8(66.67 \%)$ of the subjects are suffering from these diseases and require constant medical supplies from the hospital as depicted in Fig. 6. 
Six of the elderly community in the care center undesirably have both hypertension and diabetes diseases. One subject in particular is afflicted by the kidney stone. A total of 9 (75\%) participants are heavy smokers while 3 (25\%) never smoke or have quit smoking for more than 10 years. Two participants in particular (aged 64 and 69 years old) have been smoking for more than 50 years.

Surprisingly, majority of the blood pressure (BP) level of the care centre community (7 subjects or 58.33\%) falls in the normal level (BP between 140/90 - 90/60). Meanwhile, $4(33.33 \%)$ subjects are experiencing high blood pressure (BP > 140/90) and one is in the low blood pressure category (BP < 90/60). Based on the classification of blood pressure level by the Malaysia Clinical Practice Guidelines (Ministry of Health Malaysia, 2016), one subject in particular is in the hypertension stage II category but was never taken to hospital for treatment and did not consume any blood pressure medication.

The prevalence of hyperglycemia (blood sugar level $>5.5 \mathrm{mmol} / \mathrm{l}$ ) is high in the elderly of the care centre with 11 $(91.67 \%)$ of them are in this category and only one is having normal blood sugar level at $5.2 \mathrm{mmol} / \mathrm{l}$. One of the subjects who is the youngest in the care centre community (aged 50) has the highest and alarming blood sugar level at $21.1 \mathrm{mmol} / \mathrm{l}$. $\mathrm{He}$ also falls in the underweight category due to strict dietary intake in order to lower the insulin resistance and stabilizing blood sugar.

Table 2 - Distribution of weight and smoking prevalence of the study sample

\begin{tabular}{cccc}
\hline \multirow{2}{*}{ Variables } & \multicolumn{3}{c}{ Total } \\
\cline { 2 - 4 } & n & $\%$ & Mean (SD) \\
\hline Sample size & 12 & 100 \\
Current weight in kg: & - & - & $65.24(7.49)$ \\
Estimated height in m: & - & - & $1.80(0.05)$ \\
Estimated BMI in kg/m² : & - & - & $20.26(2.73)$ \\
Smoking & & & \\
Yes & 9 & 75.00 & - \\
No & 3 & 25.00 & - \\
\hline
\end{tabular}

\section{Common disease in study sample}

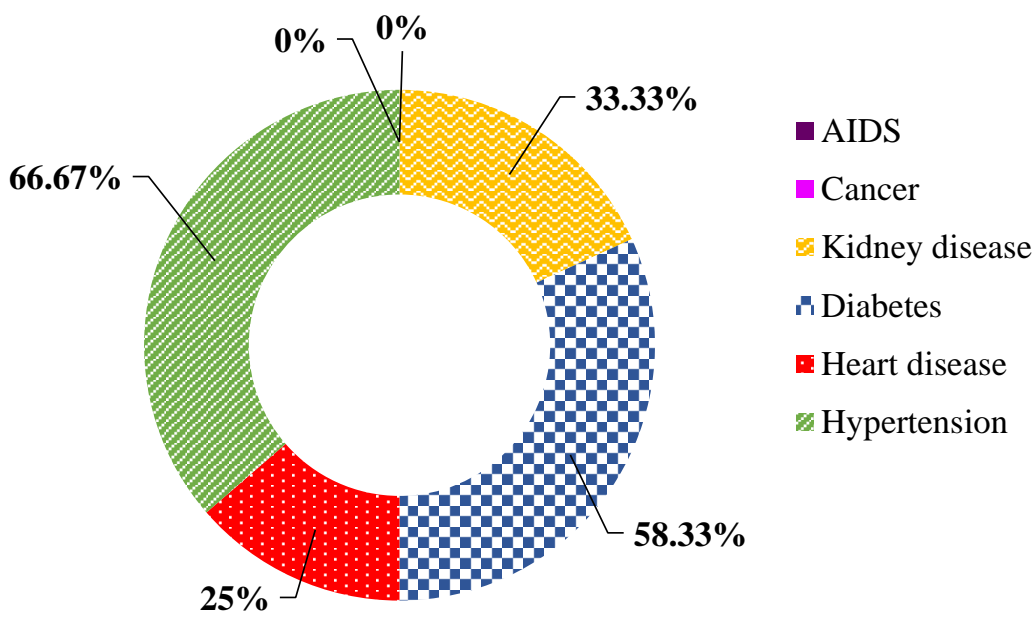

Fig. 6 - Percentage of common diseases among the study sample 


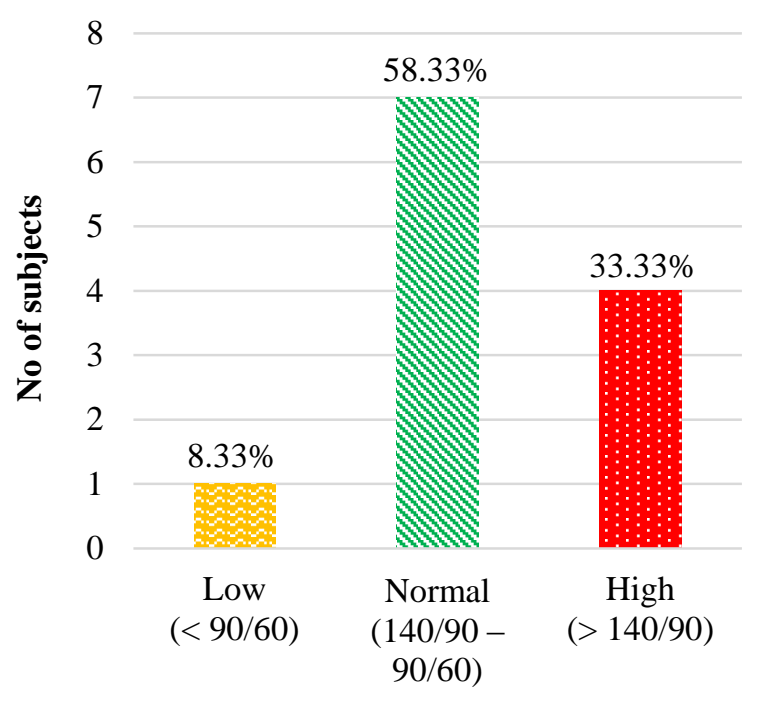

Blood Pressure

(a)

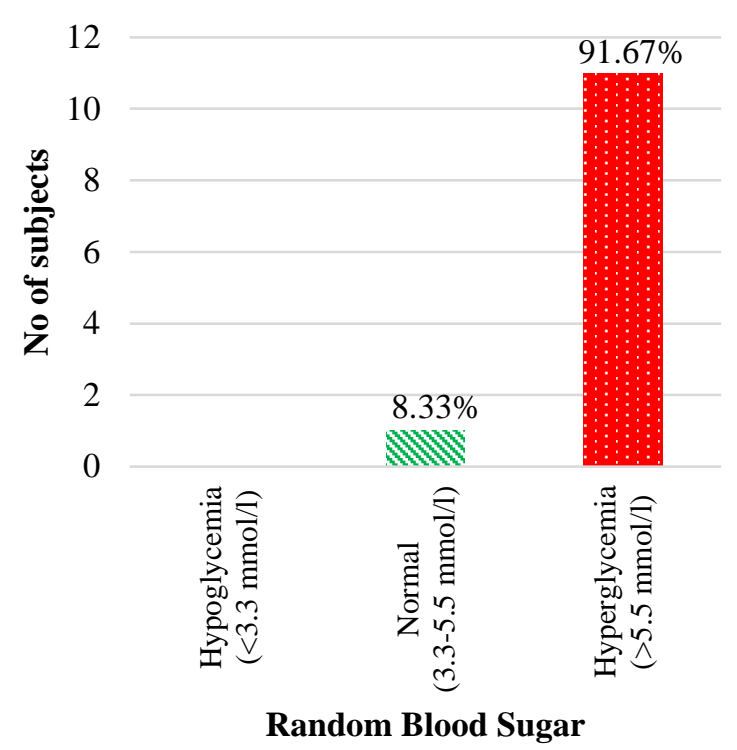

(b)

Fig. 7 - Distribution of measured (a) blood pressure and (b) random blood sugar

\subsection{Hand Grip and Pinch Strength Measurement}

Hand dominance is important in measuring performance of motor skills in daily activities. Medical conditions such as stroke and arthritis can cause impairment to both dominant and non-dominant hand thus affected the physical movement in many situations. Fig. 8 shows the relationship of several diseases with handgrip measurement. In most cases, it can be seen that those with diagnosed heart disease, diabetes or hypertension have higher mean handgrip strength than those without it. This is due to undiagnosed subjects having dysfunctional dominant hand thus had to use their other hand, which resulted in lower handgrip strength. It is interesting to note that those with diabetes produced lower mean handgrip strength compared to other diseases. This is in agreement with many studies (Mainous et al., 2015 \& Lee et al., 2018) that relates the lower handgrip strength to poor muscle quality, loss of muscle mass and diabetic hand syndrome, which eventually promote insulin resistance and causes the metabolic syndrome and diabetes (Sayer et al., 2005).

Initially, majority of the participants $(\mathrm{n}(\%)=6(50.00 \%))$ were right-hand dominant with $3(25.00 \%)$ participants were left-hand dominant and the other $3(25.00 \%)$ participants can use both hands equally well (ambidextrous) as shown in Fig. 9. However, due to stroke and arthritis, there were $4(57.14 \%)$ participants who have right hand dysfunction and two participants $(28.57 \%)$ have left hand dysfunction. It was reported that one participant (14.29\%) has a dysfunction problem in both hands due to a relatively chronic stroke. A few participants who are having dysfunctional problem with their dominant hand have to train their non-dominant hand to perform daily activities such as holding spoon and feeding themselves as well as taking a bath. This motivation has allowed them to continue living their lives sufficiently if not smoothly. The overall mean (SD) of hand grip measurement is 122.30 (65.63) Newton. Pre-elderly subjects have higher mean (SD) handgrip at 161.62 (85.235) Newton than those in elderly category with mean (SD) of 102.64 (48.269) Newton. The decreased in mean handgrip as the age increased is consistent with a study in Korean elderly community (Lee et al., 2012).

An independent t-test is employed to investigate the means of hand grip measurement of 2 groups of age, pre-elderly group which aged range between 50-59 years and an elderly group, those with age $\geq 60$ years. For $95 \%$ of confidence level of comparing means of handgrip measurement between pre-elderly and elderly group, and the width of $95 \%$ confidence interval (CI), a significant level of p-value $<0.05$ is considered to be statistically significant. Effect size is calculated to investigate the magnitude of difference between the groups of subjects. From the study, there is a statistically no significant difference on handgrip measurement between pre-elderly and elderly group, $\mathrm{t}(10)=1.56, \quad \mathrm{p}=0.150$. Handgrip measurement for pre-elderly group $(\mathrm{M}=161.62, \mathrm{SD}=85.235)$ Newton is statistically similar with elderly group $(M=102.64, S D=48.269)$ Newton. However, the magnitude of the differences in the mean is large $\quad\left(\eta^{2}\right.$ $=0.196)$. This indicate that although the mean between two groups report as not statistically significant difference, but there is a big gap of means of handgrip measurement for pre-elderly group vs elderly group $(\mathrm{M}=161.62 \mathrm{vs} \quad \mathrm{M}=$ 102.64 ) with similar dispersion dataset respectively ( $\mathrm{SD}=85.235$ vs $\mathrm{SD}=48.269)$. 

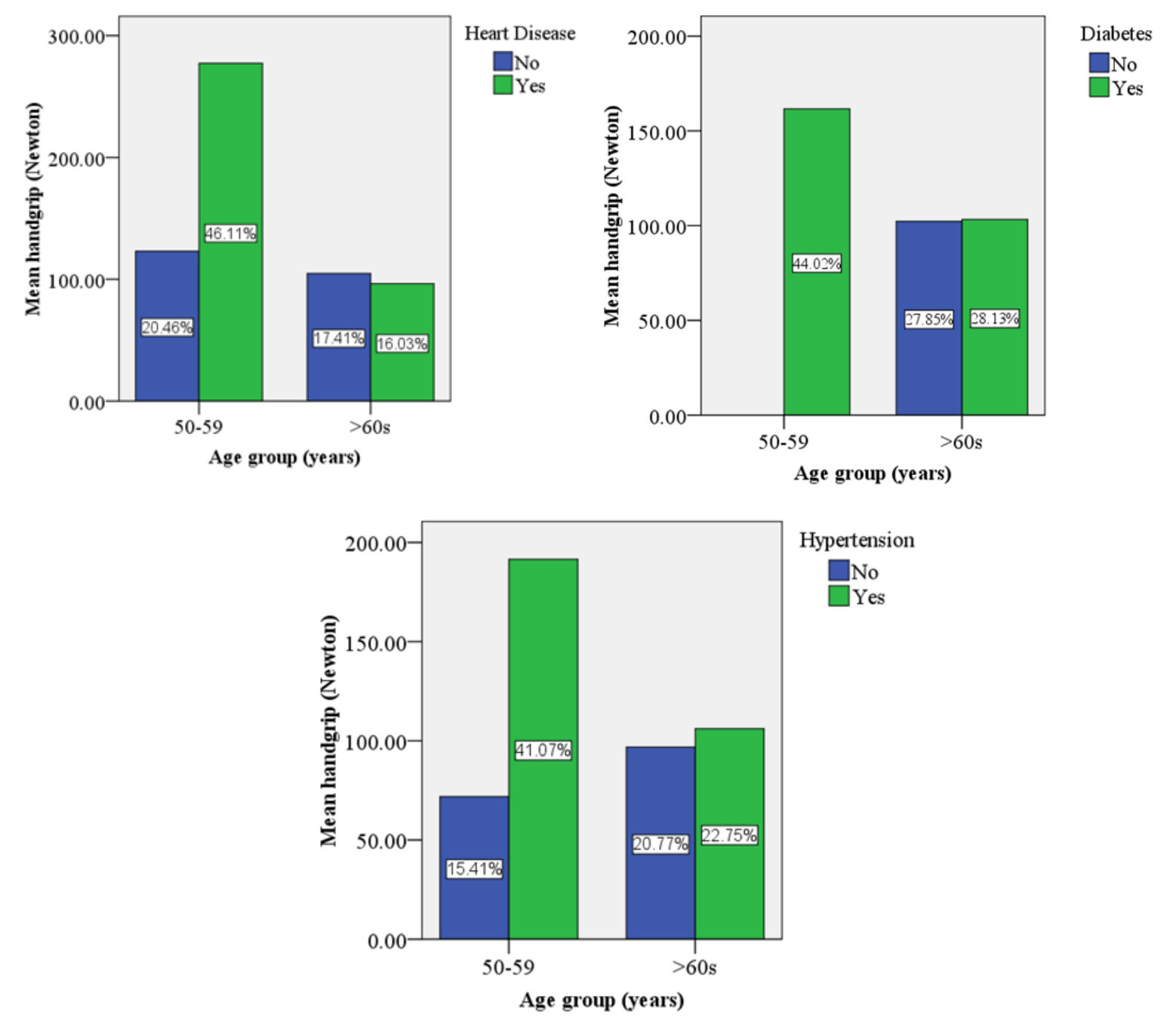

Fig. 8 - Relationship of several diseases with handgrip measurement

Dysfunctional Hand

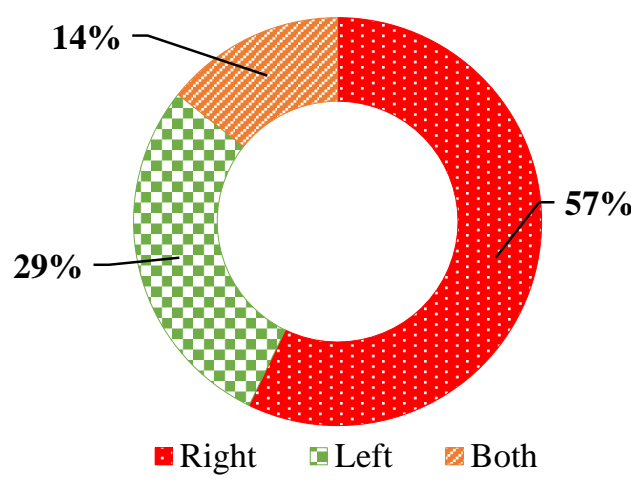

(a)

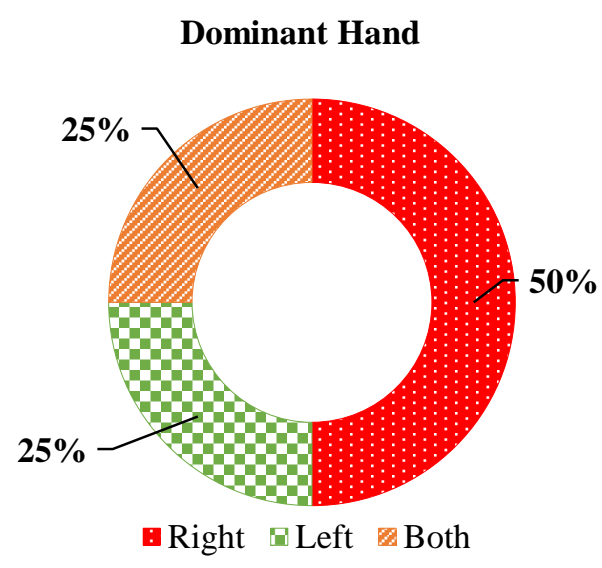

(b)

Fig. 9 - Percentage of (a) dysfunction hand and; (b) dominant hand of elderly people. 
Fig. 10 shows the relationship of handgrip measurement and smoking status. It was also found that those who have been smoking for more than 10 years have lower handgrip measurement as compared to those who never smoke or have quit smoking for more than 10 years. The two participants that have been smoking for more than 50 years have the lowest handgrip measurements at between 8 to $10 \mathrm{~kg}$ for pre-elderly and elderly categories. This finding is coherent with another study in Korean elderly community (Quan, Jeong \& Kim, 2013). and suggested that smoking is associated with body mass density (BMD) by decreasing and weakening the muscle strength. As implied by many studies (Lunenfeld \& Stratton, 2013, \& Hickson, 2006) the handgrip strength measurement can be an indicator of overall muscle strength.

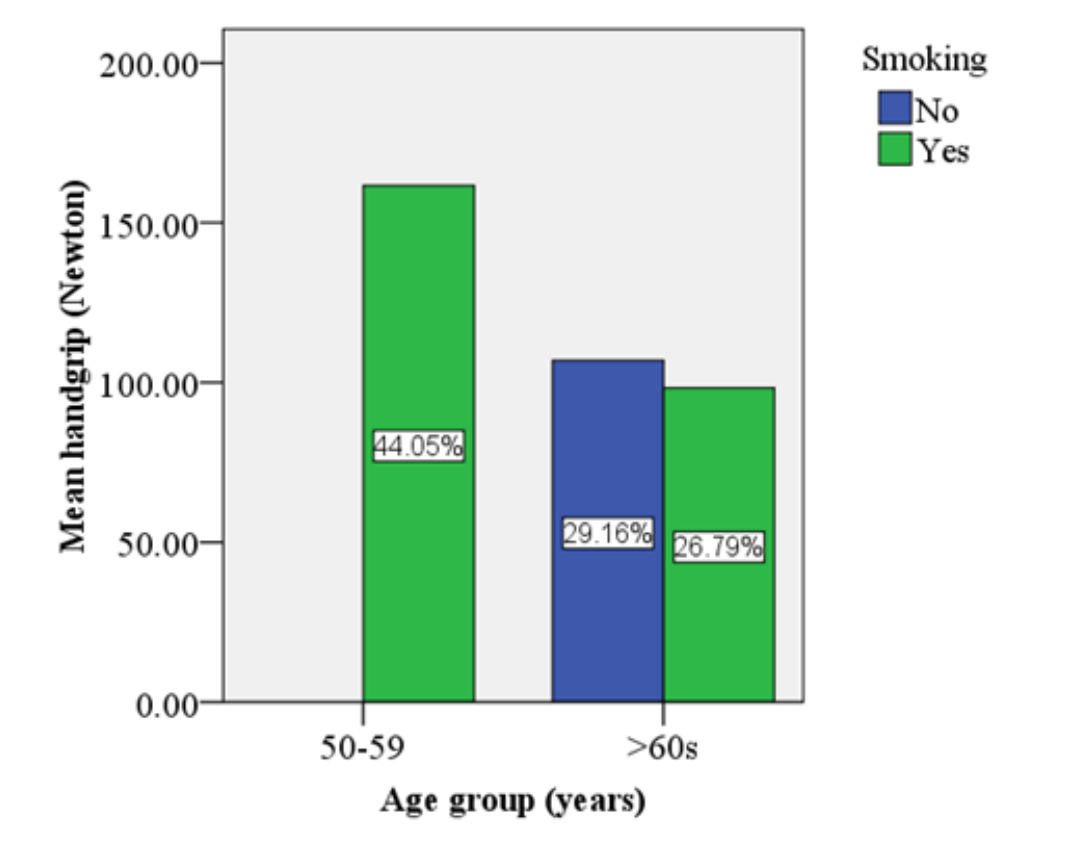

Fig. 10 - Relationship of handgrip measurement and smoking status

\subsection{Hand Functionality and Disability}

Hand functionality is an important aspect in everyday life. The hand functionality and disabilities of the elderly community is measured using QuickDASH questionnaire. Table 3 shows the QuickDASH score in the elderly community while Fig. 11 shows the percentage of the community and their ability in using the hand for daily activities, difficulty to sleep and the hand symptoms. The mean (SD) score is 42.045 (26.46), showing a moderate disability in the community. There are 4 (33.33\%) elderly who scored below 25 (mild difficulty with none scored zero. The lowest score obtained is 6.82 where the subject is quite active and has no difficulty in performing daily activities but due to his diabetic problem, he has slight difficulty to sleep and having tingling sensation on his hand. Majority of the elderly community $(\mathrm{n}$ (SD) = 5 (41.67)) scored between 25 and 75 while $3(25 \%)$ of the community is in the severe disability group (scored more than 75). The highest score obtained is 77.27 where the subject is unable to use both of his hand to conduct recreational and daily activities due to severe rheumatoid arthritis. One subject in particular has been having sleep insomnia for 10 years and sometimes require sleeping pills to fall asleep.

Table 3 - Disabilities of Arm, Shoulder and Hand

\begin{tabular}{lccc}
\hline \multirow{2}{*}{ Variables } & \multicolumn{3}{c}{ Total } \\
\cline { 2 - 4 } & $\mathbf{n}$ & \% & Mean (SD) \\
\hline QuickDASH Score & 12 & 100.00 & 42.045 \\
$(0-100)$ & & & $(26.46)$ \\
$x \leq 25$ & 4 & 33.33 & - \\
$25<x<75$ & 5 & 41.67 & - \\
$x \geq 75$ & 3 & 25.00 & - \\
\hline
\end{tabular}




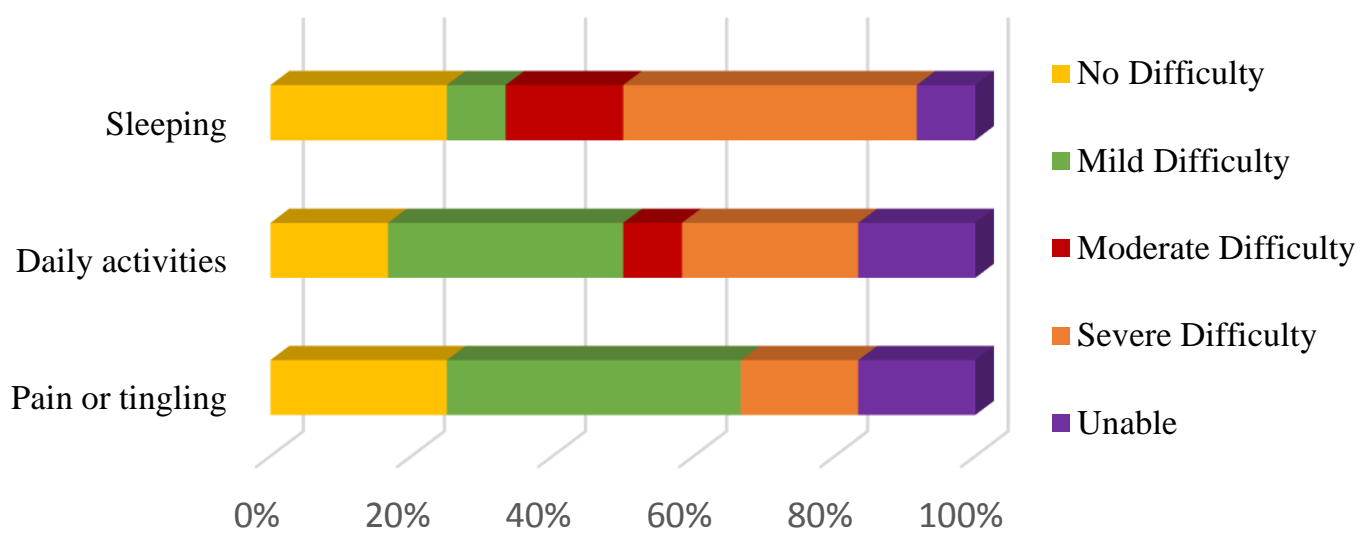

Fig. 11 - Percentage of subjects' symptoms as well their ability to perform daily activities.

\section{Conclusions}

This study has been conducted on the pre-elderly and elderly people at an Elderly Care Centre in Selangor, Malaysia. For this study, the sociodemographic data, handgrip strength measurement and hand functionality were recorded for all occupants. Overall, the mean BMI of the elderly falls in the normal and healthy weight category despite the visible nutritional deficiencies sign and symptoms on their physical body and facial. The handgrip strength measurements are quite low due to age factor and it was also found that those who have been smoking for more than 10 years have lower handgrip measurement than the others. Those with diagnosed diabetes have lower handgrip strength compared with other diseases. It was also found that there is a statistically no significant difference on handgrip measurement between preelderly and elderly group. The prevalence of hyperglycemia is high in the elderly of the care centre and in some subjects are quite alarming. Majority of the elderly community is in the moderate disability group while minority of the community is in the severe disability group with one subject in particular is unable to use both of his hand due to severe rheumatoid arthritis. By having this handgrip value and assessing the hand disability of the elderly community, physical therapist can help to design physical activities and rehabilitation exercises that are suitable for the elderly people based on their conditions. On top of that, the caretaker at the care centre can be trained to monitor the usage of rehabilitation equipment by the elderly people to avoid unnecessary incidents due to over exercising.

\section{Acknowledgement}

The author would like to thank Ministry of Higher Education (MOHE), Malaysia and Universiti Teknologi Malaysia (UTM) (Research cost centre no. Q.K130000.2540.16H95 and ) for funding this project. The author also wishes to thank the management and administration of the Elderly Care Centre for the support given throughout the project. This survey form has been copyrighted with reference no LY2017004331 (MyIPO) and IP/CR/2017/0191 (UTM).

\section{Appendix A: Questionnaire}

The questionnaire and form used for this study is as attached. The questionnaire is conducted in Bahasa Malaysia. 


\section{BORANG KAJI SELIDIK}

Pembangunan Kelestarian Kesihatan dan Kecergasan Pusat Jagaan Orang Tua.

Maktuman: Soal selidik ini adalah sebahagian danipado fasa pengumpulan data bagi Projek Pembanguma Kelestarian Kesihatan dan Kecergasan Pusat Jagaa Orang yang dianjurkan oleh UTM RAZAK Segala maklumat yang diperolehi adalah setelah mendapat keizinan daripada subjek. Semua maktumat adalah SULIT dan hanya digumakan umtuk tujuan ilmiah/ akademik sematc.

\section{BAHAGIAN 1: MAKLUMAT DIRI}

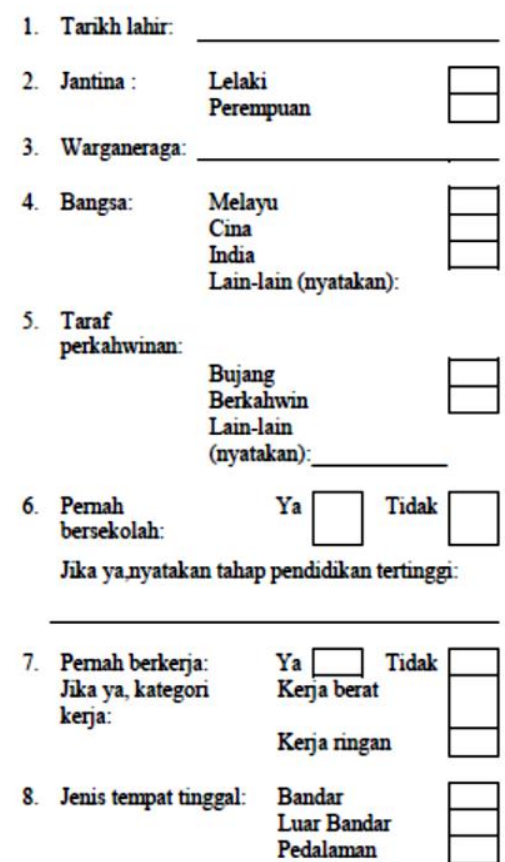

\section{BAHAGIAN 2: MAKLUMAT KESIHATAN}

1. Berat terkini (kg):

Berat 1 bulan lepas $(\mathrm{kg})$ Berat 6 bulan lepas $(\mathrm{kg})$

Berat dua minggu lepas:

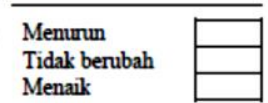

2. Tinggi $(\mathrm{cm})$

atail panjang Ulna $(\mathrm{cm})$

3. Nilai BMI: atau lilitan pertengahan lengan atas (MUAC) (cm)

4. Ukur lilit pinggang $(\mathrm{cm})$ :

5. Adakah anda atau keluarga anda mempunyai penyakit: penyalit AIDS Kanser

Penyakit buah pinggang Diabetes Penyakit jantung

Hipertensi / Darah tingg

6. Adakah anda ada

a. Alergi makanan : Jika ya, nyatakan

b. Alergi ubat : Jika ya, nyatakan

c. Merokok: Jika ya, nyatakan berapa lama

d. Mengambil ubat tertentu: Jika ya, nyatakan: Ya $\square$ Tidak $\square$

7. Adakah anda sedang $\mathrm{Ya} \square$ Tidak demam?

Jika ya, nyatakan suhu $\left({ }^{\circ} \mathrm{C}\right)$ : Berapa lama sudah demam (jam/hari) Jenis ubat yang dimakan

\section{BAHAGIAN 4 : PENGUMPULANDATA}

\section{Tangan dominan: Kanan \\ Kiri \\ Kedua-duanya}

2. Tangan disfungsi: Kanan

Kin

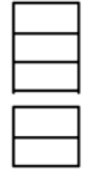

3. Adakah anda pernah mengalami:

a. Pembedahan pada mana-mana bahagian tangan dalam 3 bulan yang lepas

b. Sakit atau terhad pergerakan pada tangan atau jari disebabkan arthritis, tendinitis, carpal tunnel syndrome atau lain-lain

c. Tangan disimen

d. Luka terbuka, luka biasa atau lebam pada tangan atau jari

e. Memakai tangan atau jari palsu

4. Postur ketika ukuran di buat: Baring

$$
\begin{aligned}
& \text { Duduk } \\
& \text { Berdin }
\end{aligned}
$$

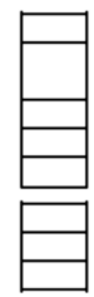

5. Ukuran genggaman tangan (Newton):

a. Bacaan pertama

b. Bacaan kedua

c. Bacaan ketiga

5. Ukuran picitan tangan (Newton):

a. Bacaan pertama

b. Bacaan kedua :

c. Bacaan ketiga : 


\section{References}

[1] United Nations (UN). (2013). World Population Ageing 2013. Population Division, Department of Economic and Social Affairs, ST/ESA/SER.A/348, UN: New York

[2] World Assembly on Aging. (1982). Vienna International Plan of Action on Aging: [World Assembly on Aging, Vienna, Austria]. New York: United Nations.

[3] WHO Expert Committee on Health of the Elderly \& World Health Organization. (1989). Health of the elderly : report of a WHO Expert Committee [meeting held in Geneva from 3 to 9 November 1987]. Geneva : World Health Organization. Available at http://www.who.int/iris/handle/10665/39521

[4] Ministry of Health. (1999). National health policy for older persons. Retrieved report at https://www.kpwkm.gov.my/kpwkm/uploads/files/Dokumen/Dasar/Dasar\%20Kesihatan\%20Warga\%20Emas\%20 Negara.pdf

[5] The Department of Statistics Malaysia. (2017). Selected demographic statistics estimates of Malaysia, population and demographic. Retrieved at https://www.dosm.gov.my/

[6] The Department of Statistics Malaysia. (2016). Malaysia population projection 2010-2040. Retrieved at https://www.dosm.gov.my/

[7] Lunenfeld, B., \& Stratton, P. (2013). The clinical consequences of an ageing world and preventive strategies. Best Practice \& Research. Clinical Obstetrics \& Gynaecology, 27(5), 643-659.

[8] Hickson, M. (2006). Malnutrition and ageing. Postgraduate Medical Journal, 82(963), 2-8.

[9] Harding, M. (2016). Muscle weakness and fatigue. Article retrieved at http://patient.info/health/muscleweakness

[10] Özbilgin, Ş., Hanc1, V., Ömür, D., Özbilgin, M., Tosun, M., Yurtlu, \& S., Arkan, A. (2016). Morbidity and mortality predictivity of nutritional assessment tools in the postoperative care unit. Medicine, 95(40), e5038.

[11] Chao, P.-C., Chuang, H.-J., Tsao, L.-Y., Chen, P.-Y., Hsu, C.-F., Lin, H.-C., \& Lin, C.-F. (2015). The Malnutrition Universal Screening Tool (MUST) and a nutrition education program for high risk cancer patients: strategies to improve dietary intake in cancer patients. BioMedicine, 5(3), 17.

[12] Keetarut K., Zacharopoulou-Otapasidou S., Bloom S., Majumdar A. \& Patel P.S. (2017) An evaluation of the feasibility and validity of a patient-administered malnutrition universal screening tool ('MUST') compared to healthcare professional screening in an inflammatory bowel disease (IBD) outpatient clinic. Journal of Human Nutrition and Dietetic, 30, 737-745

[13] Kim, E. J., Yoon, Y. H., Kim, W. H., Lee, K. L., \& Park, J. M. (2013). The clinical significance of the mininutritional assessment and the scored patient-generated subjective global assessment in elderly patients with stroke. Annals of Rehabilitation Medicine, 37(1), 66-71.

[14] Shahvazi, S., Onvani, S., Heydari, M., Mehrzad, V., Nadjarzadeh, A., \& Fallahzadeh, H. (2017). Assessment of nutritional status using abridged scored patient-generated subjective global assessment in cancer patient. Journal of Cancer Research and Therapeutics, 13, 514-8

[15] Vaz, M., Thangam, S., Prabhu, A. \& Shetty, P.S. (1996). Maximal voluntary contraction as a functional indicator of adult chronic undernutrition. British Journal Nutrition. 76, 9-15.

[16] Sharma, P., Abdul Rauf, A.M., Agarwal, R., Tyagi, P., \& Arora, A. (2017). Handgrip strength as an important bed side tool to assess malnutrition in patient with liver disease. Journal of Clinical and Experimental Hepatology, 7(1), $16-22$

[17] Jensen, K. C., Bellini, S. G., Derrick, J. W., Fullmer, S. \& Eggett, D. (2017). Handgrip strength and malnutrition (undernutrition) in hospitalized versus nonhospitalized children aged 6-14 years. Nutrition in Clinical Practice, 32, 687-693

[18] Bani, N.A., Noor, N.M., Aris, S.A., Muhtazaruddin, M.N., Kaidi, H.M., Jalil, S.Z., Usman, S.B., MuhammadSukki, F., \& Mas'ud, A.A. (2017). A preliminary study on the hand grip and pinch strength among adults in an indigenous people community in royal belum Forest, Malaysia. TENCON 2017 - 2017 IEEE Region 10 Conference, 2099-2103.

[19] El-Katab, S., Omichi, Y., Srivareerat, M. \& Davenport, A. (2015). Pinch grip strength as an alternative assessment to hand grip strength for assessing muscle strength in patients with chronic kidney disease treated by haemodialysis: a prospective audit. Journal of Human Nutritional Diet, 9(1), 48-51.

[20] Chang, Y.T. , Wu, H.L., Guo, H.R., Cheng, Y.Y., Tseng, C.C., Wang, M.C., Lin, C.Y. \& Sung, J.M. (2011). Handgrip strength is an independent predictor of renal outcomes in patients with chronic kidney diseases, Nephrol Dial Transplant, 26(11), 3588-3595.

[21] Nunes, P.M. , Guimarães de Oliveira, D., Aruin, A.S., \& José dos Santos, M. (2012). Relationship between hand function and grip force control in women with hand osteoarthritis. Journal of Rehabilitation Research and Development Service, 49 (6), 855-866.

[22] Dedeoğlu, M, Gafuroğlu, Ü., Yilmaz, Ö. \& Bodur, H. (2013). The relationship between hand grip and pinch strengths and disease activity, articular damage, pain, and disability in patients with rheumatoid arthritis. Turkish Journal of Rheumatology, 28(2), 069-077. 
[23] Sokran, S.N., Mohan, V., Kamaruddin, K., Sulaiman, M.D., Awang, Y., Othman, I.R. \& Victor, S.J. (2015). Hand grip strength and myocardial oxygen consumption index among coronary artery bypass grafting patients, Iran Journal of Medical Science, 40(4), 335-40.

[24] Ahmad, N.S., Victor Paulraj, S.J.P \& Vetrayan, J. (2013). Pinch and grip strength in adults with de quervain tenosynovitis: Malaysian population. World Applied Sciences Journal, 26 (11), 1451-1453.

[25] Taha, Z. \& Sulaiman, R. (2011). A biomechanical study of grip and pinch strength among malaysian elderly population, Pertanika Journal of Science \& Technology, 19 (2), 293 - 305.

[26] Luna-Heredia, E., Martin-Pena, G. \& Ruiz-Galiana, J. (2005). Handgrip dynamometry in healthy adults. Journal of Clinical Nutrition, 24, 250-258.

[27] Schlussel, M.M., Dos Anjos, L.A., De Vasconcellos, M.T. \& Kac, G. (2008). Reference values of handgrip dynamometry of healthy adults: a population-based study. Clinical Nutrition, 27, 601-607.

[28] Kamarul, T., Ahmad, T.S. \& Loh, W.C.Y. (2006). Hand grip strength in the adult Malaysian population, Journal of Orthopaedic Surgery, 14(2), 172-177.

[29] Bidaurrazaga-Letona, I., Esain, I., Gil, S.M., \& Rodriguez-Larrad, A. (2017). Health-related quality of life, handgrip strength and falls during detraining in elderly habitual exercisers. Health and quality of life outcomes, 15, 226.

[30] BAPEN, UK (1992). Estimating height from ulna length, Retrieved from http://www.bapen.org.uk/

[31] MIE Medical Research Ltd. (2015). Digital Pinch/Grip Analyser, United Kingdom, Retrived from https://www.mieuk.com/pgripmyo/index.html

[32] American Society of Hand Therapists (ASHT Editor) (1981). Clinical Assessment Recommendations. Garner, NC.

[33] Ministry of Health Malaysia. (2016). Management of hypertension $4^{\text {th }}$ edition, clinical practice guidelines. ISBN 978-967-12406-0-1,Retrieved from http://www.moh.gov.my/penerbitan/CPG2017/Hypertension1.pdf

[34] Mainous, A. G., Tanner, R. J., Anton, S. D., \& Jo, A. (2015). Grip Strength as a Marker of Hypertension and Diabetes in Healthy Weight Adults. American Journal of Preventive Medicine, 49(6), 850-858.

[35] Lee, M.-R., Jung, S. M., Bang, H., Kim, H. S., \& Kim, Y. B. (2018). Association between muscle strength and type 2 diabetes mellitus in adults in Korea: Data from the Korea national health and nutrition examination survey (KNHANES) VI. Medicine, 97(23), e10984.

[36] Sayer, A.A., Dennison, E.M., Syddall, H.E., Gilbody, H.J., Phillips, D.I., Cooper, C. (2005). Type 2 diabetes, muscle strength, and impaired physical function: the tip of the iceberg? Diabetes Care, 28(10), 2541-2542.

[37] Lee, J. E., Kim, K. W., Paik, N.-J., Jang, H. C., Chang, C. B., Baek, G. H., \& Gong, H. S. (2012). Evaluation of factors influencing grip strength in elderly koreans. Journal of Bone Metabolism, 19(2), 103-110.

[38] Quan, S., Jeong, J. \& Kim, D. (2013). The relationship between smoking, socioeconomic status and grip strength among community-dwelling elderly men in korea: hallym aging study. Epidemiology Health, 35, e2013001. 